Article

\title{
Framing the Shades of Sustainability in Health Care: Pitfalls and Perspectives from Western EU Countries
}

\author{
Elio Borgonovi ${ }^{1}$, Paola Adinolfi ${ }^{2, *}$,, Rocco Palumbo ${ }^{2}\left(\mathbb{D}\right.$ and Gabriella Piscopo ${ }^{2}$ \\ 1 Department of Social and Political Science, University “Luigi Bocconi” of Milan, 20154 Milano, Italy; \\ elio.borgonovi@unibocconi.it \\ 2 Department of Management \& Innovation Systems, University of Salerno, 84084 Fisciano, Italy; \\ rpalumbo@unisa.it (R.P.); gpiscopo@unisa.it (G.P.) \\ * Correspondence: padinolfi@unisa.it
}

Received: 31 October 2018; Accepted: 25 November 2018; Published: 27 November 2018

\begin{abstract}
Sustainability is momentous for the appropriate functioning of health care systems. In fact, health and sustainability are two strictly related values, which could not be separately sought. While studies discussing the contextualization of this issue with respect to the distinguishing attributes of health care systems are rapidly blooming, there is still little agreement about what is ultimately meant by sustainability in the health care arena. On the one hand, attention is primarily focused on the proper use of available financial resources; on the other hand, people engagement and empowerment are gradually arising as a crucial step to enhance the viability of the health care system. This paper tries to identify, from a conceptual point of view inspired by the European integrative movement, the different shades of sustainability in health care and proposes a recipe to strengthen the long-term viability of health care organizations. The balanced mix of financial, economic, political, and social sustainability is compelling to increase the ability of health care organizations to create meaningful value for the population served. However, the focus on a single dimension of sustainability is thought to engender several side effects, which compromise the capability of health care organizations to guarantee health gains at the individual and collective levels. From this standpoint, further conceptual and practical developments are envisioned, paving the way for a full-fledged understanding of sustainability in the health care environment.
\end{abstract}

Keywords: sustainability; health care; financial sustainability; political sustainability; social sustainability; health policy; national health service; health services

\section{Introduction}

The ongoing scientific and technological progress throughout the 20th century and at the beginning of the 21st century significantly has enhanced the ability of health care systems to meet the growing health needs and expectations of the community [1]. Inter alia, these advancements have allowed Western European countries to strengthen their welfare systems, introducing more extensive and generous health protection and health promotion services in order to merge two concurring aims: (a) improving the well-being of the population served and (b) increase the political legitimacy of governing bodies [2]. Nevertheless, the acceleration of scientific and technological developments requires the allocation of additional resources to the health care budget: this circumstance struggles with the financial and social challenges raised by the waxing globalization [3]. In fact, globalization entails a gradual shift of available resources from Western developed countries to emerging and developing economies, thus impairing the ability of the former to sustain their well-established and comprehensive welfare systems [4]. The recent financial crisis further exacerbated this situation, stimulating Western European Countries to embrace austerity measures in an attempt to save 
resources and to address them to short-term interventions aimed at boosting economic growth [5]. The attachment of the "sustainability" label to this kind of measures has produced a lot of confusion [6]; in particular, it has led to conceive sustainability as a constraint, rather than a requisite for the appropriate functioning of the health care system: it restrains the generosity and the comprehensiveness of welfare services provided to citizens and impoverishes the health conditions of the whole population in an attempt to restore financial and economic equilibria.

In light of these considerations, it is not surprising that scholars are paying growing attention to the adaptation of the "sustainability" concept to health care systems [7,8]. As argued by Guidotti [9], sustainability and health should be understood as two strictly related constructs: on the one hand, it is argued that "... health is automatically improved by commitment to sustainability"; on the other hand, it is assumed that "... sustainability provides a framework within which health gains and reduction in health disparities is possible and greatly facilitated" (p. 357). Conceptual and empirical studies investigating the interdependencies between health services' provision and sustainability promotion-at both the strategic, organizational, and management levels-are rapidly blooming. As highlighted in Figure 1, a compound search for "sustainability" and "health care" in the field "Article Title, Abstract and Keywords" of Elsevier's Scopus ${ }^{\circledR}$ —one of the largest citation databases currently available—revealed that more than 7500 papers dealing with these topics have been published in the last 30 years, with a spiralling growth since the beginning of the 21st century.

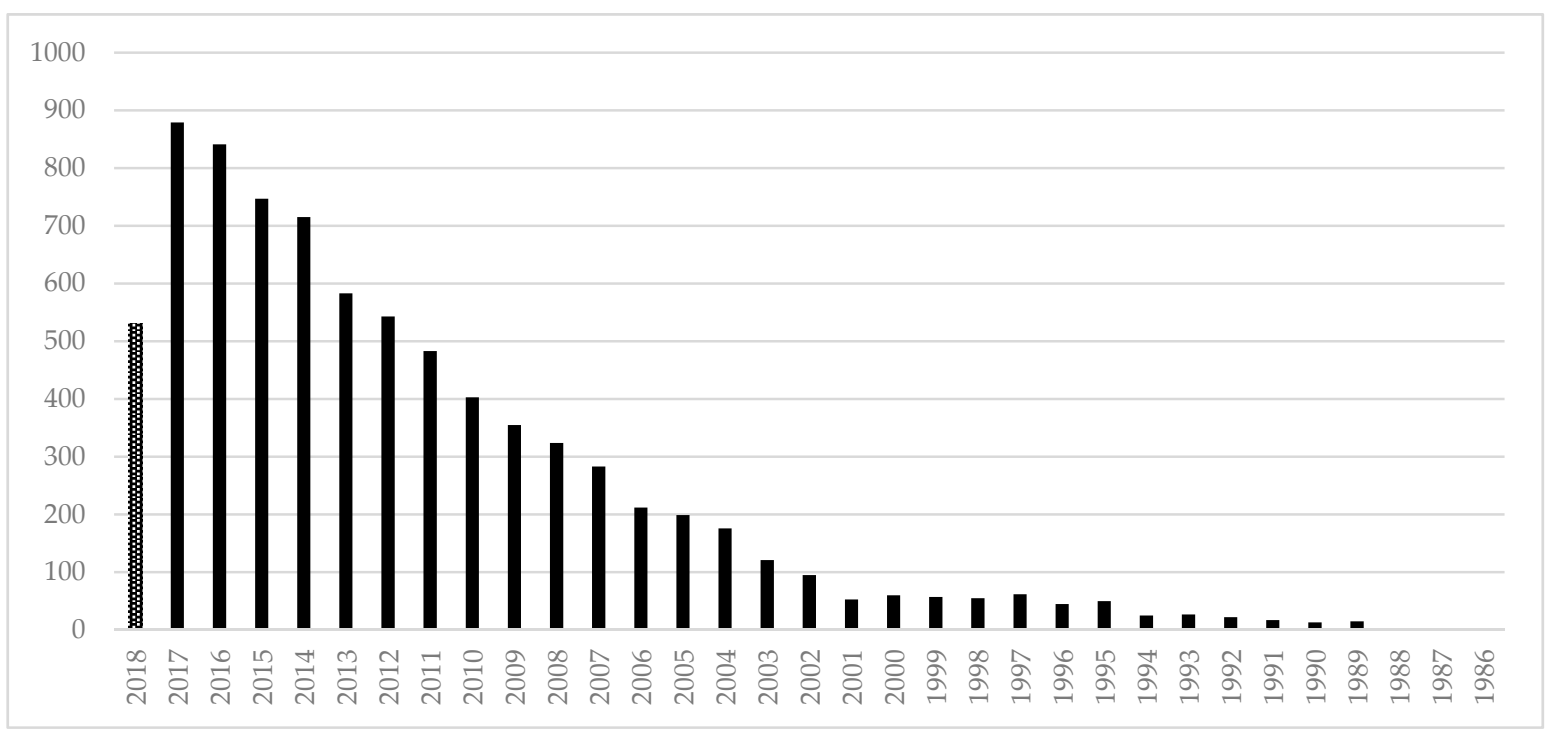

Figure 1. The spiralling growth of studies dealing with sustainability and health care. Completed years in full black, running year (2018) in dotted black. The query [TITLE-ABS-KEY ("sustainability") AND TITLE-ABS-KEY ("health care" OR "healthcare")] was run in Scopus ${ }^{\circledR}$ main search field — https: / / www.scopus.com/search/form.uri?display=basic — on 4 October 2018. Scopus®is currently one of the world's largest abstract and citation databases of peer-reviewed literature; it indexes more than 1.4 billion cited references dating back to 1970. It covers many scientific and technical disciplines, ranging from social sciences to medicine.

Nevertheless, there is a limited agreement within both the professional and the scientific literatures about what is ultimately meant by sustainability in the health care context, as well as about the interventions that should be implemented to improve the long-term viability of the health care system $[10,11]$. Firstly, it is not clear how sustainability—as an overarching concept—could be defined to make it more manageable by policy-makers and administrators [12]. Secondly, it is not easy to obtain a thorough and meaningful assessment of sustainability-related issues in the health care environment; rather, synthetic and consistent scales addressed to measure the degree of sustainability of health care structures and practices are missing [13]. Thirdly, it is possible that both communication and 
perception biases prevent the appropriate communication of sustainability-related issues among relevant stakeholders, such as policy-makers, managers, patients, and citizens; on the opposite, sustainability generates various emotions and feelings in different categories of stakeholders [14]. Lastly, yet importantly, the rooting of these biases is able to impede the process of organizational and cultural change brought by sustainability initiatives; moreover, such biases nourish unsustainable behaviors, which impair the viability of health care organizations [15].

Sticking to the definition proposed by the World Health Organization (WHO) [16], sustainability broadly involves the "... ability to meet the needs of the present without compromising the ability to meet future needs" (p. 5). Embracing this perspective, sustainability implies the capability of health care organizations to effectively use available resources to optimize health services' provision and improve achievable health outcomes [17]. This circumstance has a twofold implication in terms of intergenerational equity: in the first place, the effective use of current assets reduces the use of loan financing to subsidize health services' provision; in the second place, the health gains achieved through appropriate access to care empower the current population to produce greater value for forthcoming generations.

At the system level, this requires the achievement of financial sustainability [18]. In general terms, financial sustainability engenders the enhancement of the health care system's long-term capacity to collect an adequate amount of financial assets to face the three major challenges that, nowadays, strain the proper functioning of health care organizations across the world: (a) the increasing financial pressures generated by the widespread diffusion of health-related technologies and innovations [19]; (b) the need for timely institutional, structural, and management changes brought by the epidemiological transition toward the prevalence of long-term diseases [20]; and (c) the growing health needs expressed by the community, due to the gradual—but steady—process of population ageing $[21,22]$. It is worth noting that the effective use of available resources depends, at the organizational level, on the accomplishment of economic sustainability [23], which derives from the improvement of health care providers' ability to maximize the value they are capable to obtain from the provision of health services [24]. Obviously, value maximization is realized by avoiding the misuse of current health-related resources and promoting patients' appropriate access to care [25].

The mix of financial and economic sustainability has been variously considered to be the silver bullet to overcome the current period of distress and management difficulties faced by health care organizations in Western Countries [26]. Actually, the attainment of financial and economic equilibrium is variously thought to enact a virtuous and self-nourishing cycle of: (a) cost reduction in the delivery of care; (b) increased quality of health services; and (c) better health outcomes [27,28]. In turn, the interplay between these factors contributes to the viability of the health care system. However, the exclusive focus on financial and economic issues is not consistent with the interpretation of health care as a complex adaptive system $[29,30]$. In fact, health care systems are not characterized by single points of control. On the opposite, they are likely to show unpredictable and uncontrollable emergent behaviors [31]. Therefore, the assumption that sustainability at the financial and the economic levels is sufficient, on its own, to enhance the effectiveness of the health care system and to overcome the momentous challenges which affect the performance of health care organizations neglects the wicked nature of sustainability-related issues [32,33]. In this case, they are depreciated as mere tame problems [34], which are described by easily definable elements and may be solved by strategies which are objectively verifiable and replicable [35]. Nevertheless, as compared with tame issues, wicked problems have no definite formulation, evolve and mutate over time, and cannot be settled by clear-cut and generalizable solutions [36,37].

Recognizing both the complex nature of health care systems and the wicked nature of sustainability challenges [38], this paper attempts to illuminate the different shades which concur to frame the idea of sustainability in the health care environment. In addition, it tries to provide some food for thought for both policy-makers and managers to mold the future shapes of the health care system. For this purpose, a conceptual perspective is adopted. In the first step, sustainability itself 
is presented as a multifaceted and evolving concept, which should be comprehensively appreciated in order to improve the ability of health care organizations to generate meaningful value for the community. In light of this conceptualization, a recipe to enhance the long-term viability of the health care system is suggested, striving to account for the different shades that compose a sustainable health care system.

The paper is organized as follows. Section 2 delves into the multifaceted interpretation of sustainability, shedding light on its financial, economic, political, and social components. Section 3 emphasizes that focused interventions intended to boost sustainability at only one level are likely to produce relevant side effects on the appropriate functioning of health care organizations; these negative effects should be promptly recognized and curbed, in order to avoid unforeseen negative effects on patients' equitable access to care. Sticking to these arguments, Section 4 provides a brief overview of policy, organizational, and management interventions which could be implemented to increase the long-term viability of the health care system and, therefore, to enhance individual and collective well-being. Section 5 briefly discusses the need for a multi-layered approach to address sustainability-related issues, suggesting several streams for further developments. Also, it summarizes the main implications which could be drawn from this conceptual study, stressing the fundamental role of sustainability in crafting the health policies and strategies of the future.

\section{Highlighting the Different Shades of Sustainability in Health Care}

As anticipated in the introductory section, a multifaceted understanding of sustainability is required to comprehensively account for its distinguishing attributes as well as for its potential implications in the health care organizations' ability to produce meaningful value for the community. The different shades of sustainability are peculiar in their definition, assessment, communication, and implications for relevant stakeholders. It is worth noting that the mutual and evolving interdependencies between the different shades composing the sustainability concept are at the basis of the wicked nature of this issue. Such a wickedness is thought to generate huge and unpredictable consequences on the long-term viability of health care organizations, with direct and indirect drawbacks at both the individual and the collective levels.

\subsection{The Conventional Shade: Financial and Economic Sustainability}

Caught in the stranglehold of increasing health needs and spiralling costs, health care systems in Western Europe are facing a troublesome scenario [39,40]. Various drivers concur in worsening this situation. The joint effects of population ageing, epidemiological shift, and scientific progress trigger an increasing demand for health-related services, putting under stress the health care organizations' responsiveness [41]. In most of cases, the supply side of the health care system shows several shortcomings-ranging from diseconomies of scale to disintegration in the provision of health services-which impoverish the effectiveness of health services' provision and do not allow to meet the evolving needs of the population served [42]. In addition, policy decisions about the allocation of available financial resources may prioritize current basic levels of care, overlooking the need for investing in innovative technologies, organizational change, and advanced infrastructures; however, missing innovation and change are expected to generate in the future increased costs for health services' provision [43]. What is even more relevant is that the recent financial crisis impaired the ability of National Health Services to afford the historical health expenditure and to meet the growing health needs of the community. The introduction of austerity measures has been intended to reduce the financial exposure of the public payer to subsidize health services' provision [44,45]. As a consequence, the growing co-participation of patients to financing health care provision through out-of-pocket payments entails the expansion of inequalities in the access to care [46]. As clearly shown in Figure 2, more than a quarter of European citizens (26.5\%) self-report unmet health needs, due to waiting times $(18.70 \%)$, financial reasons $(14.80 \%)$, or long distances to access the needed health-related services (3.60\%). 
To overcome this demanding situation, the strengthening of financial sustainability at the system level and the advancement of economic sustainability at the organizational level have been identified as two unavoidable steps [47,48]. Firstly, financial sustainability is aimed at gradually rebalancing the financial inflows and outflows of the health care system, in an attempt to curb the burden produced by the steadily growing amount of debts generated by publicly financed health care provision. Besides, it is targeted to realize a more effective allocation of available financial resources and, therefore, to obtain increased cost effectiveness in the delivery of health promotion and health protection services. Secondly, economic sustainability is fundamental to avoid that health care organizations and providers misuse current assets to deliver inappropriate health services, which do not contribute to the achievement of health gains for both the individual and the society. Also, it allows to merge the appropriate access of patients to care with the continuous improvement of health technologies and structures, paving the way for better health outcomes.
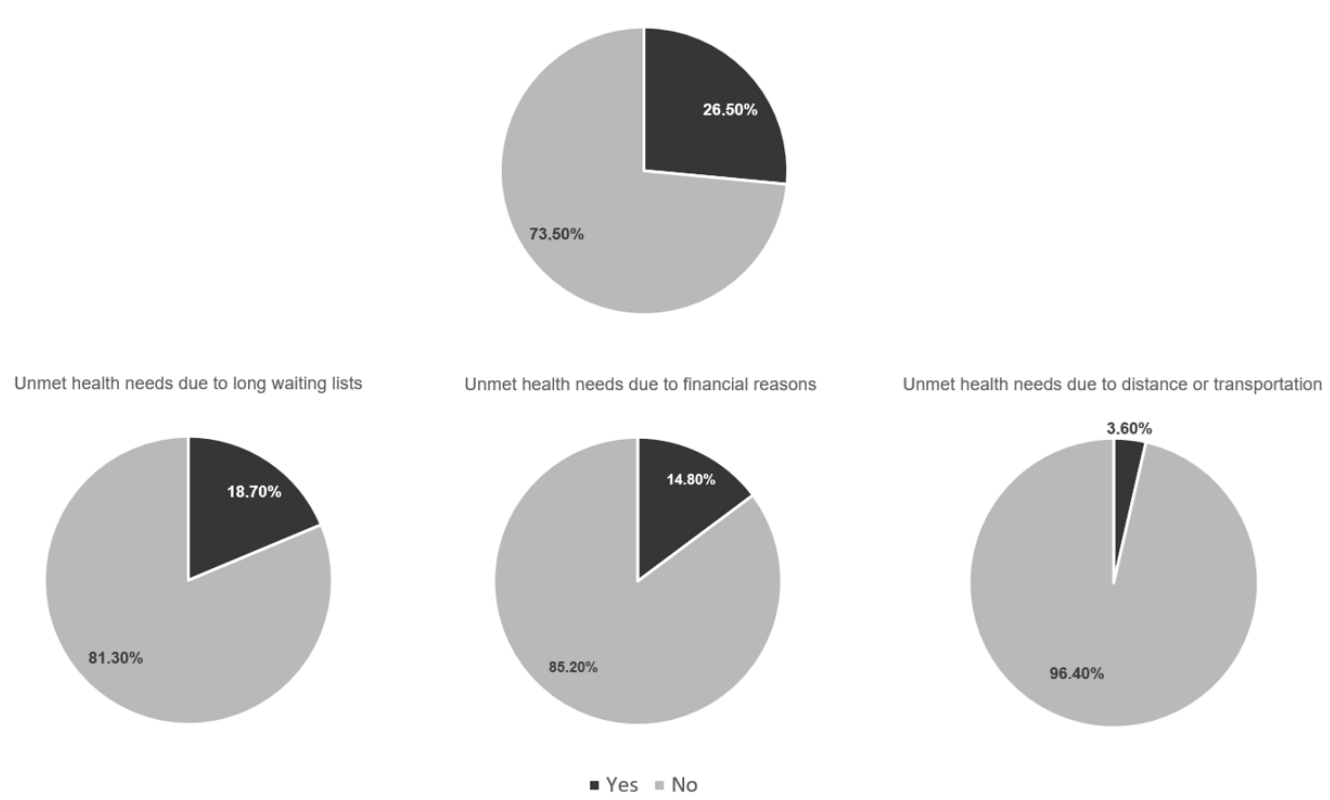

Figure 2. Unmet health needs (aggregate and for specific reasons: long waiting lists; financial reasons; distance) in the European Union (EU-28), year 2014. Authors' elaboration from Eurostat data, available at https: / / ec.europa.eu/eurostat/web/health/health-care/data/database (last accessed on 9 October 2018).

Financial and economic sustainability have been generally identified as the foundational pillars on which the viability of the health care system is established. Nevertheless, several scholars have stressed that expenditure cut and cost reduction may not be consistent with the current trends that steer the evolution of the health care system $[49,50]$. As previously anticipated, patients express growing expectations in terms of quality and variety of health services; if associated with the increasing health needs of the population, this circumstance engenders increasing health-related costs and lower health care organizations' ability to meet the users' demands [51]. At the same time, the mix of technological progress and the introduction of medical innovation boost the process of costs spiralling in the health care arena, thus undermining the viability of the whole health care system [52]. In spite of these points, the promotion of financial and economic sustainability has been generally handled as a simple and replicable solution to deal with the management challenges currently faced by health care organizations. Henceforth, rather than setting the condition for strengthening the effectiveness of health care systems, interventions intended to enhance their financial and economic sustainability have produced long-lasting side effects on their ability to provide timely and effective health services to the community. 


\subsection{The Hidden Shade: Political Sustainability}

The interpretation of health care as a complex adaptive system stresses the never-ending tension to adaptation which characterizes health care organizations [53]. Change is a regular component of health care systems [54]: it is ultimately intended to bridge the gap between the evolving needs of the population served and the intrinsic propensity of health care organizations to anchor to the structural and cultural models which are legitimated within the professional and academic communities [55]. From this standpoint, the process of change is generally initiated at the policy level, in an attempt to avoid that the inertia rooted in the conventional processes and embodied in the practices of health care organizations may thwart the adaptation of existing strategies and structures to the transformation of the environmental context [56].

In line with these considerations, the sustainability concept in the health care context assumes a political connotation [57]. To be viable, the health care system should be established on the "... long-lasting alignment of the interests and belief systems of the most important political forces shaping health policies and their implementation, namely, political parties, elected representatives, and different parts of government or different tiers of the public administration, such as central and state bodies" (p. 37). This alignment is imperative to create an institutional climate which is receptive to change and which empowers health care organizations and professionals to accommodate the evolving expectations of the community. Political sustainability prevents the nurturing of tacit and explicit conflicts among the different parties that participate in steering the health care system. Since institutional conflicts represent a relevant burden for the ability of health care organizations to provide timely and effective health services to the community, political sustainability turns out to be essential for the long-term viability of the health care system. It encourages all relevant institutional stakeholders to play a propelling role in designing and implementing meaningful processes of change, thus boosting the continuous adaptation of health care institutions to the evolving dynamics of the external environment [58].

It is worth noting that political sustainability does not solely involve consonant and non-conflicting relationship between the political parties and the institutions which are variously involved in the complex process of molding and continuously reshaping the structures and the processes of the health care system. Also, it requires the active participation of citizens-both individually and through collective actions-in sustaining the policy directions which guide the development of the health care system [59]. Beyond supporting policy-making, citizens involvement in participatory governance is expected to generate multiple positive impacts on health care, which are made possible by the greater awareness of the community about the specific policy challenges which affect the viability of health care organizations $[60,61]$. However, in countries where the presence of a well-established National Health Service guarantees the universal access of the community to care (such as Italy and United Kingdom), people may attach lower urgency to health-related issues as compared to other social affairs, such as migration, safety, and unemployment; in turn, this generates lower participation to the health policy discourse. As shown in Figure 3, European citizens are consistent in perceiving a limited degree of trust in the political systems, which further discourage citizens' engagement.

On the average, European citizens express a low level of trust in the political system (3.5 on a scale from 1 to 10). The lower scores are shown by Mediterranean European Countries with a National Health Service aiming at universal coverage through the implementation of a single public payer system, such as Portugal (1.7), Spain (1.9), Italy (2.1), and Cyprus (2.6). Differently, Scandinavian countries-which have been found to be relatively less prone to curb the public health care expenditure as a reaction to the financial crisis-report levels of trust in the political system that outpace the European average. Apparently, the lower levels of trust in the political system among Mediterranean Countries may be the aftermath of the implementation of austerity health policies directed to recovering the economic and financial sustainability of the National Health Service through spending review and cut to the provision of health services [62]. In this specific circumstance, the limited attention paid to the interplay between financial, economic, and political sustainability has engendered a sort of deterioration of the relationship between policy-makers and the population served. On the one 
hand, this situation prevents participatory governance, since it is conducive to conflict, rather than collaboration [63]; on the other hand, it undermines the overall sustainability of the health care system, engendering the rise of diverging perspectives and impaired consensus among the entities interested in the appropriate functioning of the health care system [64].
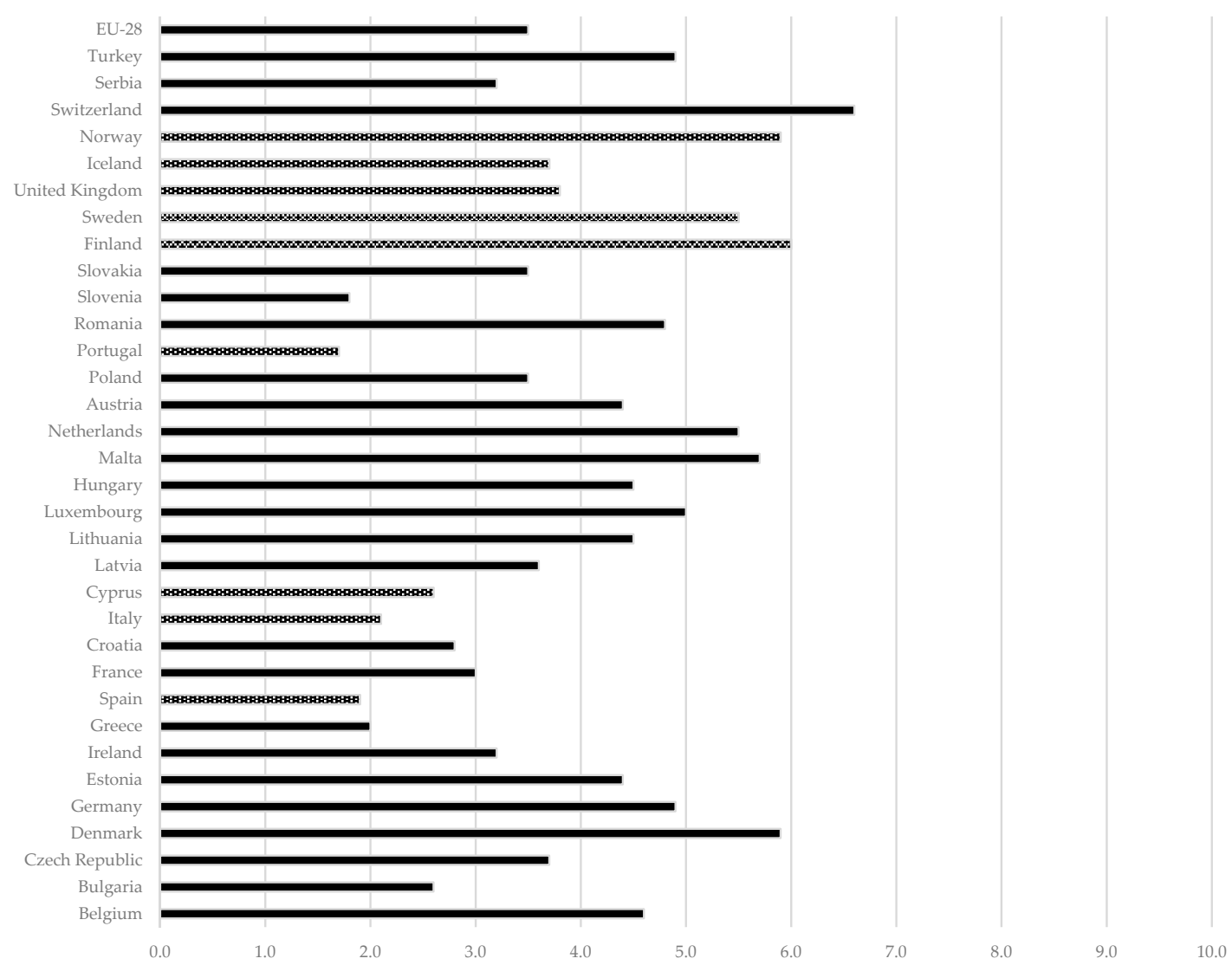

Figure 3. Average rating of European citizens' trust in the political system, Year 2013. Trust is assessed on a scale ranging from " 1 " (very low) to " 10 " (very high). European Countries with a universal health care system and a single payer system type in dotted black; other European Countries in full black. Authors' elaboration from Eurostat data, available at https: / / ec.europa.eu/ eurostat/web/productsdatasets /- /ilc_pw03 (last accessed on 9 October 2018).

\subsection{The Rooted Shade: Social Sustainability}

The idea of social sustainability is deeply entrenched in the attributes of health care systems which aim at promoting universal and fair access to care [65]. Drawing on Garcés et al. [66], social sustainability involves the ability to undertake and promote the value of intergenerational solidarity, according to which "...present freedom implies the responsibility of taking into account our successors" and "...no present or future citizen should have their freedom...impaired" by current actions (p. 210). In line with these considerations, social sustainability turns out to be a nested concept, which concomitantly implies the endorsement of different principles, including $[57,67,68]$ equality, diversity, democracy, interconnectedness, environmental friendliness, and individual empowerment.

Firstly, to be sustainable from a social perspective, the health care system should allow an equal and non-discriminatory access to care for the whole population, overcoming inequalities produced by individual socio-economic conditions $[69,70]$. Equal access requires the ability of health care providers to identify and tackle disparities in the access to health promotion and health prevention services [71]. Moreover, fair and non-discriminatory access to care relies on the health care organizations' capacity to avoid the misuse of available health assets and resources, prioritizing health services targeted to 
people with higher needs and enhancing the responsiveness of health services providers toward the evolving expectations of the community [72].

In spite of its relevance, an exclusive focus on equality is not able to pave the way for socially viable health care systems. It should be merged with the safeguard of diversity in planning, organizing, and delivering health services. In fact, equality and diversity are only at first glance contradictory values: both of them contribute to the establishment of a patient-centered approach to care, which conceives the patient as the subject-rather than the object—of health services' provision [73]. In particular, a concern for diversity involves that health policies, strategies, and plans recognize "... the sources of diversity in the societies..., including gender, race, and age" [57] (p. 36). Therefore, a focus on diversity implies the ability to design a health services' delivery system which is effective in addressing the various and unfolding health needs of different categories of patients [74-76]. Accordingly, attention to diversity is fundamental to achieve fair access to care and, therefore, to enhance the social sustainability of the health care system [77].

The balanced mix of equality and diversity leads to a democratic health care system, which recognizes and encourages the active participation of citizens and patients to the design and delivery of health services [78]. Democracy represents a cornerstone of universal systems. In fact, it allows people to achieve a greater awareness of timely health-related issues and to have a voice in steering the health discourse at both the policy and the strategic levels. This generates greater opportunities to match the demand and the supply sides of health care provision [79]. However, as displayed in Figure 4, patients may be unwilling to have an active role in performing their everyday citizenship duties. In the specific field of health care, this may be the by-product of limited individual health-related knowledge and skills [80], which discourage patients' involvement in health-related decisions as well as their engagement in health promotion and health prevention initiatives [81].

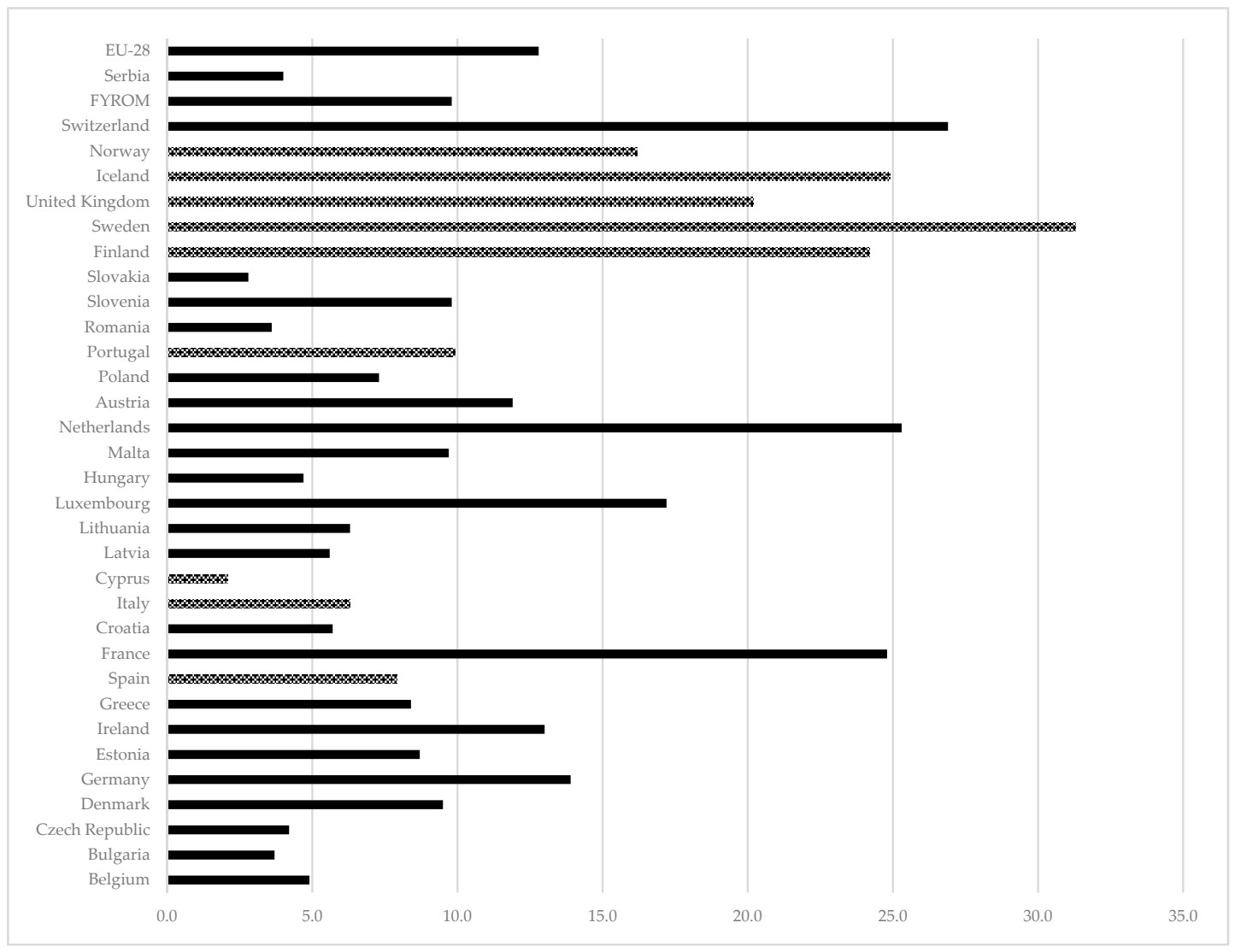

Figure 4. Participation (\%) in formal or informal voluntary activities or active citizenship, Year 2015. European Countries with universal health care and a single payer system type in dotted black. Authors' elaboration from Eurostat data, available at https:/ / ec.europa.eu/eurostat/data/database. 
It is worth noting that the lack of interconnectedness in both the structuring and the functioning of health care organizations prevents the achievement of equality, diversity, and democracy in delivering health services, thus impoverishing the social sustainability of the whole health care system. Firstly, organizational disintegration between different health services' providers hampers the patients' ability to navigate the health care system and to promptly access appropriate health-related services which match the individual health needs [82,83]. Secondly, limited levels of social interconnectedness between the different entities populating the health care environment generate increased risks of patient disempowerment [84], paving the way for the patients' unwillingness to actively participate in planning, designing, and delivering health services [85]. In light of these arguments, an effort should be realized to enhance the social connectivity and the inter-organizational relationships in the health care system, in an attempt to set the conditions for an empowering and sustainable health care system.

Social sustainability has a relevant environmental dimension. In fact, the activities of health care organizations have been argued to be especially dangerous for the environment [86], since they represent the "...only type of company which generates all existing classes of waste" (p. 8270). Lack of attention paid to the environmental shade of social sustainability engenders-at least-two significant consequences. Contributing to the declining condition of the natural environment, the environmental unsustainability of health care organizations has indirect repercussions on the population's health conditions, thus provoking increased health needs and, consequently, greater demand for care [87]. Secondly, engendering a misfit between the general purposes of health care organizations and their actual behaviors [88], it weakens the institutional legitimacy of health care institutions, thus compromising their social acceptability among relevant stakeholders.

Lastly, yet importantly, social sustainability is established on the individual social responsibility of those who are directly and indirectly involved in the provision of care [89]. In turn, the creation of individual social responsibility in the health care environment demands a process of empowerment [90], which is intended to enable the patients and their informal caregivers to perform as active service co-producers and value creators in the design and delivery of health services [91]. In other words, patients and informal caregiver should be engaged by health care providers in a co-producing partnership, which is aimed at minimizing the risks of resources' misuse. The engagement and active participation of patients and informal caregivers is critical to make people aware of the intrinsic complexity that characterizes the provision of health services, thus encouraging them to perform as co-producers of health, through higher compliance, greater willingness to self-manage individual health needs, and better consciousness of healthy life styles and behaviors [92,93].

Summarizing these arguments, Figure 5 graphically depicts the nested nature of social sustainability. Just like the wider sustainability construct, it is composed of different dimensions, which should be concomitantly contemplated in designing tailored strategies and policies intended to improve the viability of health care organizations. As outlined in the following section, the adoption of a segmented and one-sided perspective is likely to produce side effects at the individual and collective levels; in the long run, such shortcomings are expected to impair the ability of health care organizations to create meaningful value for the community and, therefore, might prevent the overall sustainability of the health care system. 


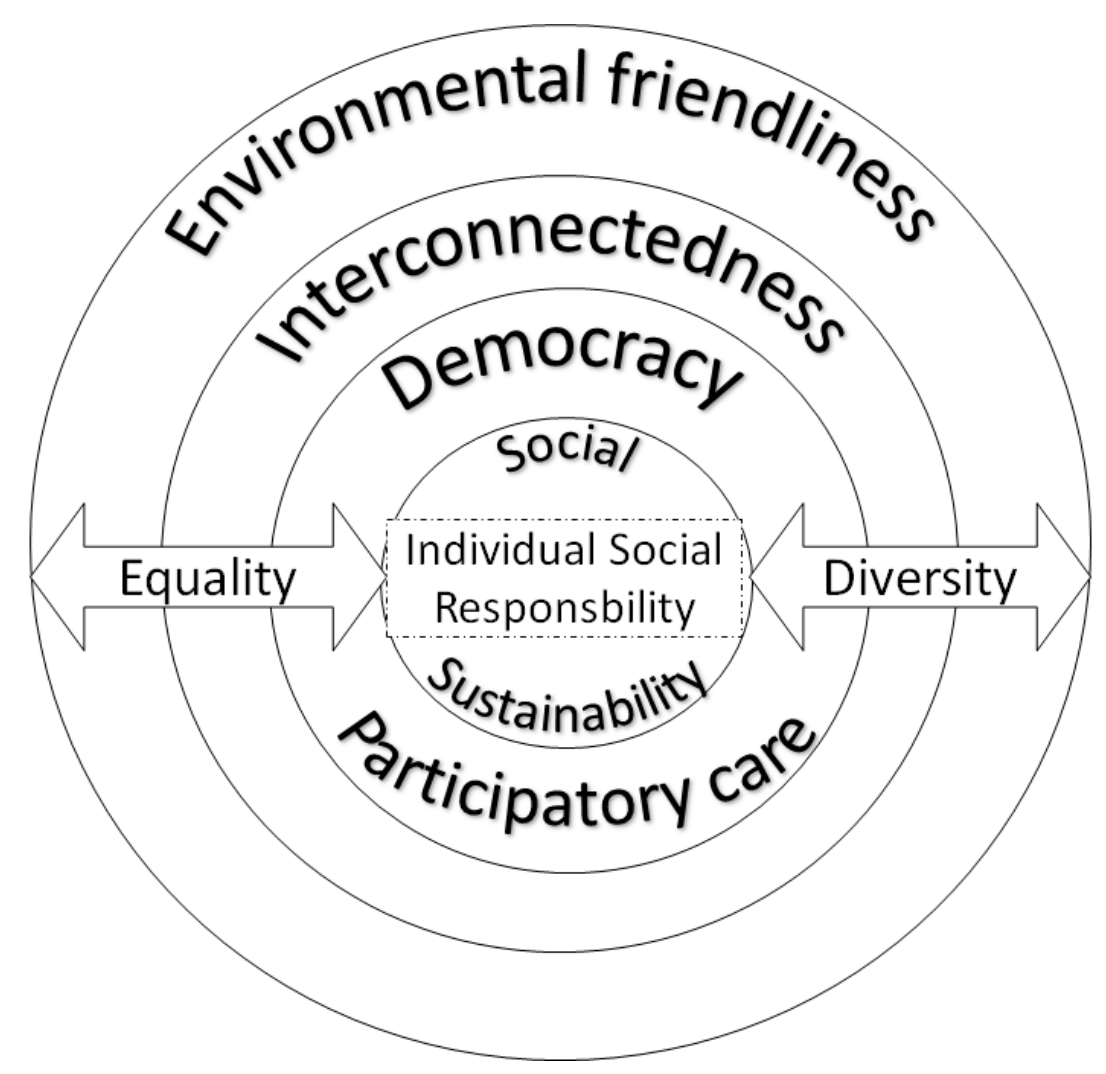

Figure 5. The "nested" nature of the "social sustainability" construct in the health care environment.

\section{Containing the Side Effects of Sustainability}

Table 1 summarizes the drawbacks which are produced by the misunderstanding of sustainability as a tame problem rather than as a wicked issue. As reported above, tame problems are specific in that they can be solved by lock-and-key solutions, which are easy to assess and to replicate in other contexts. However, these solutions are limited in that they focus on a specific dimension of the broader sustainability concept; moreover, they overlook the interplay between the various shades that contextualize sustainability in the health care environment. From this point of view, far from being effective in terms of improvement of the health care system's viability, they could entail negative implications, which jeopardize the ability of health care organizations to produce value-in terms of health-for the population served.

The strengthening of financial and economic sustainability attracted most health policy makers' attention in the past few years. Spending review and generalized cuts in health care expenditures have been identified as primary tools to deal with the massive effects of the recent financial crisis on the Western European countries' ability to guarantee universal and fair access of the community to basic levels of care $[44,94]$. Nevertheless, scholars have tried to emphasize the shortcomings of these interventions for the sustainability of the health care system [95]. These primarily originate from the lack of concern for the interplay between financial, political, and social factors. On the one hand, austerity measures undermine the political viability of the health care system. In fact, they produce side effects on the health care organizations' capacity to meet the health needs of the community, with unavoidable repercussions on both waiting lists and quality of services $[96,97]$. This situation implies a gradual degeneration of the trust perceived by citizens in the political system, as well as a decline of the institutional legitimation of health care organizations. Ultimately, these dynamics enact a vicious and self-nourishing cycle, which is expected to weaken the sustainability of the health care system. On the other hand, cuts in health care expenditures put under stress the social sustainability of the health care system. In particular, they prevent the adoption of a patient-centered approach to care and entail a reduction of the health care organizations' ability to promote equality and diversity in the 
provision of health services [98], thus leading to a disintegrated and provider-led model of care [99]. What is even more interesting is that financial and economic constraints are thought to weaken the health care organizations' willingness to improve their environmental sustainability in order to save as much resources as possible for the specific purpose of health services' delivery [100].

Table 1. The side effects of lock-and-key interventions to address the sustainability issue in health care.

\begin{tabular}{|c|c|c|c|}
\hline $\begin{array}{c}\text { Focus of } \\
\text { Interventions }\end{array}$ & Time Span & Illustrative Examples & $\begin{array}{l}\text { Potential Side Effects in } \\
\text { Terms of Sustainability }\end{array}$ \\
\hline $\begin{array}{l}\text { Financial and/or } \\
\text { economic } \\
\text { sustainability }\end{array}$ & $\begin{array}{l}\text { Short term: balancing of } \\
\text { financial/economic } \\
\text { inflows and outflows to } \\
\text { improve the health care } \\
\text { system's viability }\end{array}$ & $\begin{array}{l}\text { Cuts to health care } \\
\text { expenditures, reduction of } \\
\text { hospital beds; freeze of staff } \\
\text { turnover; spending review; } \\
\text { rationalization of health } \\
\text { services }\end{array}$ & $\begin{array}{l}\text { Impaired social sustainability } \\
\text { due to drawbacks in fair } \\
\text { access to health services; } \\
\text { negative effects on political } \\
\text { sustainability generated by } \\
\text { shrinking trust in political } \\
\text { institutions }\end{array}$ \\
\hline $\begin{array}{l}\text { Political } \\
\text { sustainability }\end{array}$ & $\begin{array}{l}\text { Medium term: consensus } \\
\text { maximization across the } \\
\text { various stakeholders } \\
\text { interested in the } \\
\text { appropriate functioning } \\
\text { of the health care system }\end{array}$ & $\begin{array}{l}\text { Alignment of potentially } \\
\text { conflicting political parties' } \\
\text { interests, such as lower } \\
\text { waiting times, increased } \\
\text { quality care, and reduction } \\
\text { in health-related costs }\end{array}$ & $\begin{array}{l}\text { Direct and indirect negative } \\
\text { consequences on the financial } \\
\text { and economic equilibria of } \\
\text { health care organizations; } \\
\text { drawbacks in social } \\
\text { sustainability due to lower } \\
\text { equity in the access to care }\end{array}$ \\
\hline $\begin{array}{l}\text { Social } \\
\text { sustainability }\end{array}$ & $\begin{array}{l}\text { Long term: optimizing } \\
\text { the satisfaction of } \\
\text { stakeholders' current } \\
\text { interests without } \\
\text { compromising the } \\
\text { freedom of future } \\
\text { generations }\end{array}$ & $\begin{array}{l}\text { Enhancement of equality } \\
\text { and diversity in the access to } \\
\text { care through increased } \\
\text { interconnectedness and } \\
\text { greater patients' } \\
\text { participation }\end{array}$ & $\begin{array}{l}\text { Increased health-related costs } \\
\text { and deterioration of financial } \\
\text { sustainability; mounting } \\
\text { conflicts between divergent } \\
\text { political parties' interests }\end{array}$ \\
\hline
\end{tabular}

In a quite similar way, the exclusive focus on political sustainability may generate negative effects on both financial and social sustainability. Political sustainability aims at aligning the interests and beliefs of the different political forces which concur in shaping health policies and in implementing them. This requires the contemporary pursue of potentially conflicting interests and objectives, such as cost containment and health services' quality improvement [101]; also, it involves the search of an equilibrium between divergent perspectives, including the tension to the marketization of health services and the safeguarding of universal coverage [102]. From this point of view, there is the risk that the achievement of political sustainability leads to the impairment of financial and social sustainability. Firstly, political sustainability is demanding in terms of resources' use, unbalancing the financial and economic equilibria of health care organizations [103]. Secondly, it may neglect the role played by equality in underpinning the social sustainability of the health care system, focusing on the principle of diversity in order to increase the political acceptability of measures and interventions directed to reframe the structures and the functioning of health care organizations [104].

Lastly, the spotlight on social sustainability entails trade-offs with both financial and political sustainability. The commitment to realizing the values of democracy, equality, diversity, interconnectedness, environmental friendliness, and individual social responsibility in the health care context implies increasing costs, which are not consistent with the decline of public resources available to subsidize the functioning of the health care system. The promotion of social sustainability undermines the strengthening of financial and economic sustainability, impairing the long-term viability of the health care system. At the same time, social sustainability does not necessarily trigger political sustainability: rather, it could determine greater conflicts among the political forces which are involved in reshaping the health care system. In fact, the latter have been thought to strive for achieving local and egoistic purposes, which are not conducive to sustainability [105]. 
In light of these arguments, policy and strategic and management initiatives intended to enhance the viability of the health care system should rely on a balanced mix of interventions concomitantly targeted to the various dimensions of sustainability. Sticking to this assumption, the following section proposes a recipe for long-term sustainability in the health care system: far from representing a one-size-fits-all approach, this proposal should be understood as a flexible framework, which should be carefully adapted to the contextual factors and the inner characteristics of different types of health care systems aiming at the achievement of long-term sustainability [106].

\section{A Recipe for Long-Term Sustainability?}

The recipe for long-term sustainability in health care requires the balanced mix of various ingredients, each of which is expected to improve the viability of the health care system from the financial, economic, political, and social points of view [57,107]. This approach is useful to tackle the "... triumph of imbalance" [108] (p. 5) which is currently affecting Western societies. To handle such an imbalance, multifaceted interventions are concomitantly required, allowing to deal with the various sources of uncertainty and complexity that affect the functioning of health care organizations [109].

Drawing on Mintzberg [108], the rebalancing of the health care systems to achieve increased levels of long-term sustainability should be established on three pillars, which are situated in different areas of the society: the public, the private, and the plural realms. Even though these sectors are thought to simultaneously contribute to the enhancement of the different shades of sustainability depicted above, each of them is especially fitting with the improvement of financial, economic, political, or social sustainability. Besides, beyond their individual contribution, their systemic role in augmenting the ability of the health care system to produce meaningful value for the community should be taken into consideration: particular attention should be paid to the interplay between them and to the synergies that could be activated across different sectors to increase the long-term viability of the health care system.

While the strengthening of health care systems' financial and economic sustainability has been mainly dealt with as an issue which is circumscribed within the boundaries of the public system, a more effective way to attain it implies greater interconnectedness between the public and the private realms [110]. This does not simply involve that public sector entities operating in the health care arena mimic the organizational and managerial practices developed in the private sector in order to achieve greater efficiency and effectiveness in the provision of care [111]. On the opposite, it requires a balanced mix of public and private values, which allow to account for the complexity and variety of management challenges concerning the rebalancing of the health care system [112]: private sector entities patronize economic effectiveness and quality improvement; public sector organizations safeguard and guarantee the principle of universal and equal access to care [113]. The establishment of sound partnerships between the public and the private sectors to improve the appropriate functioning of the health system is expected to lead to the collection of additional resources, which are crucial to overcome the current period of financial restrictions faced by state-owned entities [114]. Financial and economic sustainability stems from the positive interaction between the public and the private realms, which turn out to be mutually committed to strengthening the long-term viability of the health care system.

Similarly, political sustainability could not be conceived outside the public-plural dyad. Going more into details, a multi-stakeholder perspective is essential to recognize and account for the different belief systems and interests arising around the health care system, making it easier to reconcile them. This permits to increase the acceptability and, as a consequence, the feasibility of policy and strategic interventions aimed at reframing the structures and processes of health care organizations $[115,116]$. The engagement of the society in the process of health policy-making gives voice to the special and evolving needs of the community and makes it possible to boost the responsiveness of the health care system. This leads to establishing a mutual trusted relationship between the political system and the population served, which increases the viability of health policies and the timeliness of their factual implementation. Also, it has positive implications in terms of financial sustainability, since it 
reduces the risks of resource wasting associated with the appearance of conflicts between the different stakeholders interested in the appropriate functioning of the health care system [117].

Last, but not least, social sustainability is rooted at the intersection between the public and the plural systems and between the plural and the private realms [118]. On the one hand, the synergies between the public and the plural systems fuel the promotion of diversity and equality in the access to care; they pinpoint the active participation of patients in co-planning, co-designing, and co-delivering health services, thus boosting the full-fledged democratization of the health care system [63]. Besides, they set the conditions for the establishment of a patient-centered approach to care, which determines higher opportunities to increase the access of citizens to health services, with positive spillovers on the long-term viability of the health care system [119]. On the other hand, the interactions between the private and the societal sectors pave the way for increased interconnectedness in the health care setting, leading to the foundation of a living ecosystem composed of entities interested in the joint promotion of health and sustainability [120]. The ecosystem view is essential to bridge the gap between financial and social sustainability, creating a wide commitment of all stakeholders to improve the ability of health care organizations to generate meaningful value for the community, without altering the equilibria of the external environment. Obviously, to be effective and viable, ecosystems should rely on capable and socially responsible individuals. Form this point of view, the public, the private, and the plural realms should merge their efforts to promote patients and informal caregivers' empowerment. This paves the way for the engagement of individuals as key value co-creators in the health care environment, sticking to a full-fledged perspective of patient-centered care.

\section{Concluding Remarks}

Although the scientific and technological progress has significantly contributed to the advancement of the health care systems' ability to generate value in terms of health protection and well-being improvement, sustainability seems still to be a distant goal. The growing gap between the patients' and citizens' expectations and the health care organizations' supply capacity-which is in part generated by the democratization of health information through information and communication technologies-undermines the economic and financial sustainability of health care systems. Moreover, the shrinking availability of financial resources engenders side effects in terms of equal access to care: while the wealthier classes of the population can benefit from tailored and timely health services, the poorer ones face growing barriers in accessing the basic levels of care in their everyday living environment. Obviously, this has drawbacks in terms of both political and social sustainability, impairing the institutional legitimation of health care organizations. In fact, the latter are considered to be ineffective in guaranteeing the core values of universalism, equality, and democracy, on which European national health care systems are assumed to rely. This situation is likely to trigger a mounting crisis in Western liberal democracies, weakening the trust relationship between the citizens and the institutional system.

The health policies of the last few years seem to have further exacerbated the inability of health care systems to deal with the sustainability challenge. As sketched in Figure 6, in most of cases, the priority has been to focus on financial and economic sustainability, in an attempt to recover the efficiency of health care organizations through austerity measures. Greater efficiency in the delivery of care is assumed to pave the way for social sustainability, since it permits to save resources which are reallocated to increase the quality and quantity of health services provided to disadvantaged people. In turn, the ability of health care systems to guarantee equality and diversity without compromising financial and economic equilibria is thought to engender political sustainability. However, this reasoning neglects the wickedness of sustainability-related issues, overlooking that the focus on financial and economic sustainability may prevent, rather than foster, the achievement of social and political viability. It is worth noting that health policy-makers and managers have been variously found to be unaware of the deep interdependencies existing between financial, economic, political, and social sustainability; this lack of awareness about the real nature of sustainability has 
produced momentous side effects, undermining the ability of health care organizations to manage the sustainability-health interdependence and compromising the appropriate functioning of the health care system.

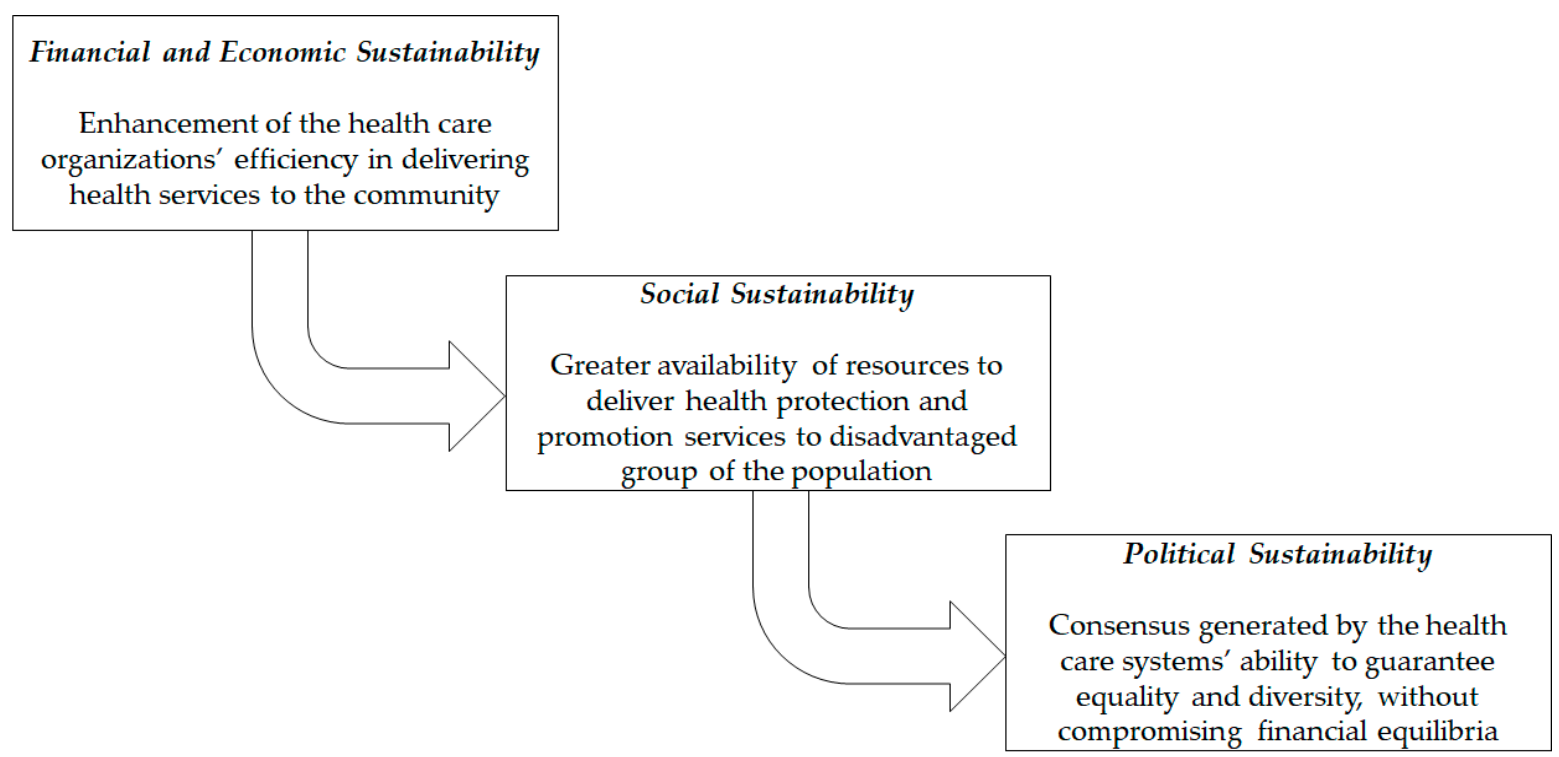

Figure 6. The linear and "tame" approach to sustainability in health policies and strategies. Authors' own elaboration.

The wicked nature of the sustainability problem requires a systemic and multi-faceted action to be properly and effectively handled. In line with this consideration, Figure 7 depicts the deep involvement of the public, the private, and the plural realms of the society in the efforts aimed at improving the viability of the health care system. While one-sided interventions are likely to generate negative implications on the capacity of health care organizations to enhance the well-being of the population served, the integration of initiatives variously targeted to the financial, economic, political, and social dimensions of sustainability is imperative to make the health care system viable in the long term. In fact, the integration of such interventions allows to acknowledge the interplay between the different shades which compose the broader sustainability construct as well as to exploit the synergies between them, sticking to a service ecosystem perspective.

Further conceptual and practical developments are needed to fully disentangle the relationships between the different shades of sustainability and to shed light on how their interplay contributes to the viability of the health care system. Inter alia, greater attention should be paid to the drawbacks originating from the inability at the policy and management levels to merge the different measures intended to promote financial and economic sustainability with the strengthening of political and social sustainability. Lack of integration between these initiatives is expected to degenerate into the worsening of the organizational climate of health care institutions, which, in turn, depletes the providers' capability to deal with the evolving health needs of their patients. Moreover, empirical studies assessing the effects of systemic interventions directed to enhance the sustainability of health care organizations are missing. The consequent prevalence of conceptual contribution over empirical analysis creates a gap between the reality and the rhetoric of sustainability in health care, which should be filled in order to fully appreciate the relevance of this phenomenon. Lastly, yet importantly, the practical approaches to sustainability enhancement which could be factually used to achieve the involvement of the various stakeholders populating the public, the private, and the plural sectors deserve strong consideration. While it is clear that systemic interventions are required to handle the complexity of sustainability-related issues, still little is known about the institutional and management tools that could be used for this purpose. 


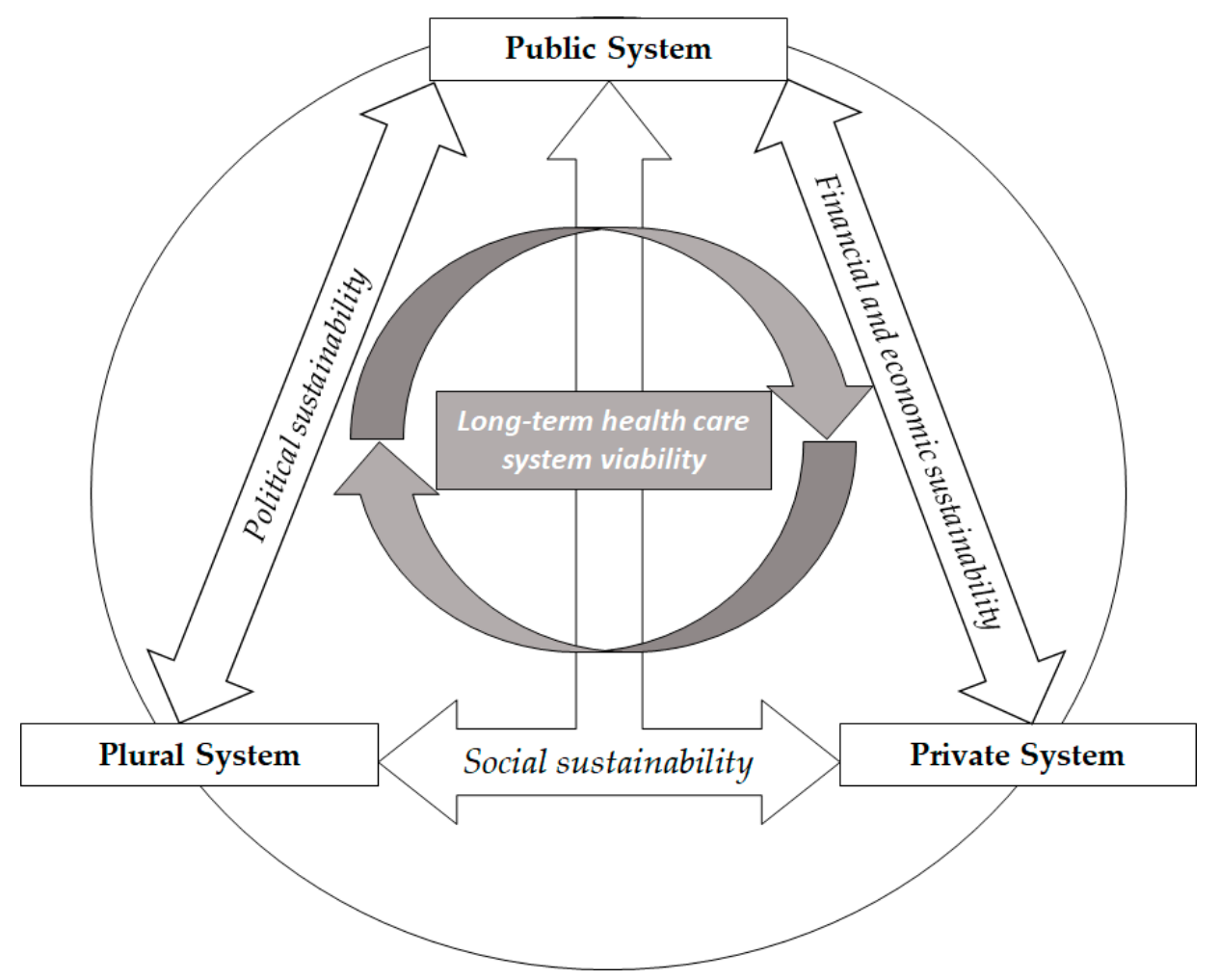

Figure 7. A systemic approach to deal with the wickedness of sustainability-related issues. Authors' own elaboration from Mintzberg [103].

In conclusion, the contribution of this study is twofold. On the one hand, it emphasizes the pointlessness of conventional lock-and-key solutions to face the sustainability challenge in the health care environment: rather than contributing to improving the health care organizations' ability to create meaningful value for the population, they are likely to entail side effects on the dynamic equilibria of the health care system, weakening its long-term viability. On the other hand, it stresses the multifacetedness of the sustainability concept: far from being understood as a clear-cut and stable phenomenon, it is concomitantly composed of various and interrelated elements, which should be simultaneously handled to strengthen the ability of the health care system to promote the well-being of the community.

Author Contributions: Conceptualization, P.A., E.B., and R.P.; Supervision, P.A. and E.B.; Visualization, P.A., E.B., and G.P.; Writing-original draft, P.A., E.B., and R.P.; Writing-review \& editing, R.P. and G.P.

Funding: This research received no external funding.

Conflicts of Interest: The authors declare no conflict of interest.

\section{References}

1. Guyatt, G.; Yalnizyan, A.; Devereaux, P.J. Solving the public health care sustainability puzzle. Can. Med. Assoc. J. 2002, 167, 36-38.

2. Immergut, E.M. Health Politics: Interests and Institutions in Western Europe New York; Cambridge University Press: Cambridge, UK, 1992.

3. Saltman, R.B.; Figueras, J.; Sakellarides, C. Critical Challenges for Health Care Reform. In Europe Maidenhead; Open University Press: London, UK, 1998.

4. Kus, B. Neoliberalism, Institutional Change and the Welfare State: The Case of Britain and France. Int. J. Comput. Soc. 2006, 47, 488-525. [CrossRef]

5. Simonet, D. Healthcare reforms and cost reduction strategies in Europe: The cases of Germany, UK, Switzerland, Italy and France. Int. J. Health Care Qual. Assur. 2010, 23, 470-488. [CrossRef] [PubMed] 
6. Pavolini, E.; Guillén, A.M. Health Care Systems in Europe under Austerity; Institutional Reforms and Performance Basingstoke; Palgrave Macmillan: Basingstoke, UK, 2013.

7. Lennox, L.; Maher, L.; Reed, J. Navigating the sustainability landscape: A systematic review of sustainability approaches in healthcare. Implement. Sci. 2018, 13, 27. [CrossRef] [PubMed]

8. Chu, K.W.K.; Cheung, L.L.W. Incorporating sustainability in small health-care facilities: An integrated model. Lead Health Serv. 2018, 31, 441-451. [CrossRef] [PubMed]

9. Guidotti, T.L. Sustainability and health: Notes toward a convergence of agendas. J. Environ. Stud. Sci. 2018, 8, 357-361. [CrossRef]

10. Rich, C.R.; Singleton, J.K.; Wadhwa, S.S. Sustainability for Healthcare Management: A Leadership Imperative; Routledge: London, UK, 2013.

11. Boone, T. Organizing for sustainability: Exploratory analysis of the healthcare industry. Int. Ser. Opt. Res. Manag. Sci. 2012, 174, 37-48.

12. Anåker, A.; Elf, M. Sustainability in nursing: A concept analysis. Scand. J. Caring Sci. 2014, 28, 381-389. [CrossRef] [PubMed]

13. Buffoli, M.; Capolongo, S.N.M.; Gherardi, G.; Gola, M. Healthcare Sustainability Evaluation Systems. In Improving Sustainability during Hospital Design and Operation. Green Energy and Technology; Capolongo, S., Bottero, M., Buffoli, M., Lettieri, E., Eds.; Springer: Cham, Switzerland, 2015; pp. 23-29.

14. Hovlid, E.; Bukve, O.; Haug, K.; Aslaksen, A.B.; von Plessen, C. Sustainability of healthcare improvement: What can we learn from learning theory? BMC Health Serv. Res. 2012, 12, 235. [CrossRef] [PubMed]

15. Buchanan, D.A.; Fitzgerald, L.; Ketley, D. The Sustainability and Spread of Organizational Change: Modernizing Healthcare; Routledge: London, UK, 2007.

16. Roberts, J.L. Terminology a Glossary of Technical Terms on the Economics and Finance of Health Services; World Health Organization, Regional Office for Europe: Geneva, Switzerland, 1998.

17. Harris, C.; Green, S.; Elshaug, A.G. Sustainability in Health care by Allocating Resources Effectively (SHARE) 10: Operationalising disinvestment in a conceptual framework for resource allocation. BMC Health Serv. Res. 2017, 17, 632. [CrossRef] [PubMed]

18. Thomson, S.; Foubister, T.; Figueras, J.; Kutzin, J.; Permanand, G.; Bryndová, L. Addressing Financial Sustainability in Health Systems; World Health Organization, Regional Office for Europe: Copenhagen, Denmark, 2009.

19. Blank, J.L.T.; Valdmanis, V.G. Technology diffusion in hospitals: A log odds random effects regression model. Int. J. Health Plan. Manag. 2015, 30, 246-259. [CrossRef] [PubMed]

20. Bigdeli, M.; Shroff, C.Z.G.I.; Ghaffar, A. Health systems research on access to medicines: Unpacking challenges in implementing policies in the face of the epidemiological transition. BMC Glob. Health 2018, 2, 941. [CrossRef] [PubMed]

21. Van Bokkelen, G.; Morsy, M.; Kobayashi, T.H. Demographic Transition, Health Care Challenges, and the Impact of Emerging International Regulatory Trends with Relevance to Regenerative Medicine. Curr. Stem Cell Rep. 2015, 1, 102-109. [CrossRef]

22. Zaidi, B.; Morgan, S.P. The Second Demographic Transition Theory: A Review and Appraisal. Annu. Rev. Sociol. 2017, 43, 473-492. [CrossRef] [PubMed]

23. Porter, M.E. What Is Value in Health Care? N. Eng. J. Med. 2010, 363, 2477-2481. [CrossRef] [PubMed]

24. Adinolfi, P.; Starace, F.; Palumbo, R. Health Outcomes and Patient Empowerment. The Case of Health Budgets in Italy. J. Health Manag. 2016, 18, 117-133. [CrossRef]

25. Palumbo, R.; Manna, R. What if things go wrong in co-producing health services? Exploring the implementation problems of health care co-production. Pol. Soc. 2018, 37, 368-385. [CrossRef]

26. Picatoste, J.; Ruesga-Benito, S.M.; González-Laxe, F. Economic environment and health care coverage: Analysis of social acceptance of access restrictive policies applied in Spain in the context of economic crisis. J. Clean. Prod. 2018, 172, 3600-3608. [CrossRef]

27. Berwick, D.M.; Nolan, T.W.; Whittington, J. The Triple Aim: Care, Health, and Cost. Health Aff. 2008, 27, 759-769. [CrossRef] [PubMed]

28. Maarse, H.; Jeurissen, P.; Ruwaard, D. Concerns over the Financial Sustainability of the Dutch Healthcare System; IFO Institute, Center for Economic Studies: Munich, Germany, 2013.

29. Rouse, W.B. Health Care as a Complex Adaptive System: Implications for Design and Management. Bridge $2008,38,17-25$. 
30. McDaniel, R.R.; Lanham, H.J.; Anderson, R.A. Implications of complex adaptive systems theory for the design of research on health care organizations. Health Care Manag. Rev. 2009, 34, 191-199. [CrossRef] [PubMed]

31. Rouse, W.B. Managing complexity: Disease control as a complex adaptive system. Inf. Knowl. Syst. Manag. 2000, 2, 143-165.

32. Kessler, R.; Glasgow, R.E. A Proposal to Speed Translation of Healthcare Research into Practice: Dramatic Change is Needed. Am. J. Prev. Med. 2011, 40, 637-644. [CrossRef] [PubMed]

33. Waddock, S. The Wicked Problems of Global Sustainability Need Wicked (Good) Leaders and Wicked (Good) Collaborative Solutions. J. Manag. Glob. Sust. 2013, 1, 91-111. [CrossRef]

34. Raisio, H. Health care reform planners and wicked problems: Is the wickedness of the problems taken seriously or is it even noticed at all? J. Health Organ. Manag. 2009, 23, 477-493. [CrossRef] [PubMed]

35. Alford, J. Wicked and less wicked problems: A typology and a contingency framework. Pol. Soc. 2017, 36, 397-413. [CrossRef]

36. Rittel, H.; Webber, M. Dilemmas in a General Theory of Planning. Pol. Sci. 1973, 4, 155-169. [CrossRef]

37. Blackman, T.; Greene, A.; Hunter, D.J.; McKee, L.; Elliott, E.; Harrington, B.; Marks, L.; Williams, G. Performance Assessment and Wicked Problems: The Case of Health Inequalities. Pub. Pol. Adm. 2006, 21, 66-80. [CrossRef]

38. Blok, V.; Gremmen, H.G.J.; Wesselink, R. Dealing with the wicked problem of sustainability: The role of individual virtuous competence. Bus. Prof. Ethics J. 2016, 34, 297-327. [CrossRef]

39. Palumbo, R. Toward a new conceptualization of health care services to inspire public health. Public national health service as a "common pool of resources". Int. Rev. Public Nonprofit Mark. 2017, 14, 271-287. [CrossRef]

40. Karanikolos, M.; Mladovsky, P.; Cylus, J.; Thomson, S.; Basu, S.; Stuckler, D.; Mackenbach, J.P.; McKee, M. Financial crisis, austerity, and health in Europe. Lancet 2013, 381, 1323-1331. [CrossRef]

41. Beard, J.R.; Bloom, D.E. Towards a Comprehensive Public Health Response to Population Ageing. Lancet 2015, 385, 658-661. [CrossRef]

42. Rosko, M.D. Understanding variations in hospital costs: An economics perspective. Ann. Oper. Res. 1996, 67, 1-21. [CrossRef]

43. Evans, R.G.; Stoddart, G.L. Producing Health, Consuming Health Care. In Barer M. Why Are Some People Healthy and Others Not? Routledge: New York, NY, USA, 1994; pp. 27-66.

44. Adinolfi, P.; Florenzano, O.; Palumbo, R. Spending review tra austerity e razionalizzazione: L'Esperienza della Regione Campania. Mecosan 2017, 104. Available online: https://www.francoangeli.it/riviste/ sommario.asp?IDRivista $=180$ (accessed on 25 November 2018).

45. Reeves, A.; McKee, M.; Basu, S.; Stuckler, D. The political economy of austerity and healthcare: Cross-national analysis of expenditure changes in 27 European nations 1995-2011. Health Pol. 2014, 115, 1-8. [CrossRef] [PubMed]

46. Kaminska, M.E.; Wulfgramm, M. Universal or commodified healthcare? Linking out-of-pocket payments to income-related inequalities in unmet health needs in Europe. J. Eur. Soc. Pol. 2018. [CrossRef]

47. Luzzard, T.; Hellström, A.; Lifvergren, S. Sustainability in Healthcare Organizations. In Management Innovations for Healthcare Organizations: Adopt, Abandon or Adapt? Örtenblad, A., Löfström, C.A., Sheaff, R., Eds.; Routledge: Abingdon, UK, 2016; pp. 338-358.

48. Mladovsky, P.; Srivastava, D.; Cylus, J.; Karanikolos, M.; Evetovits, T.; Thomson, S.; McKee, M.; World Health Organization. Health Policy Responses to the Financial Crisis in Europe; World Health Organization, Regional Office for Europe: Copenhagen, Denmark, 2012.

49. Palumbo, R. Keeping candles lit: The role of concierge medicine in the future of primary care. Health Serv. Manag. Res. 2017, 30, 121-128. [CrossRef] [PubMed]

50. Adinolfi, P. Transparency and Spending Review: A Model for Italian Healthcare. Symphonya 2017, 17, 120-134.

51. Lim, W.S.; Wong, S.F.; Leong, I.; Choo, P.; Pang, W.S. Forging a Frailty-Ready Healthcare System to Meet Population Ageing. Int. J. Environ. Res. Public Health 2017, 14, 1448. [CrossRef] [PubMed]

52. Hult, K.J.; Jaffe, S.; Philipson, T.J. How Does Technological Change Affect Quality-Adjusted Prices in Health Care? Systematic Evidence from Thousands of Innovations. Am. J. Health Econ. 2017, 4, 1-21. [CrossRef]

53. Martin, C.M. Complex adaptive systems approaches in health care-A slow but real emergence? J. Eval. Clin. Pract. 2018, 24, 266-268. [CrossRef] [PubMed] 
54. Adinolfi, P. Philosophy, medicine and healthcare: Insights from the Italian experience. Health Care Anal. 2014, 22, 223-244. [CrossRef] [PubMed]

55. Adinolfi, P. Barriers to reforming healthcare: The Italian case. Health Care Anal. 2014, 22, 36-58. [CrossRef] [PubMed]

56. Fitzgerald, L.; McDermott, A. Challenging Perspectives on Organizational Change in Health Care; Routledge: London, UK, 2017.

57. Borgonovi, E.; Compagni, A. Sustaining universal health coverage: The interaction of social, political, and economic sustainability. Value Health 2013, 16, 34-38. [CrossRef] [PubMed]

58. Dattée, B.; Barlow, J. Multilevel Organizational Adaptation: Scale Invariance in the Scottish Healthcare System. Org. Sci. 2017, 28, 301-319. [CrossRef]

59. Mountford, N.; Geiger, S. (Re)-Organizing the evolving healthcare market: Collaborative governance in bureaucratic contexts. AOM Proc. 2018, 1. [CrossRef]

60. Renedo, A.; Marston, C. Spaces for Citizen Involvement in Healthcare: An Ethnographic Study. Sociology 2015, 49, 488-504. [CrossRef] [PubMed]

61. Mattei, P.; Mitra, M.; Feiler, T. The Politics of 'Social Accountability' in England and Germany: Democratic Control and Moral Imperatives. Public Org. Rev. 2018, 18, 399-411. [CrossRef]

62. Van Gool, K.; Pearson, M. Health, Austerity and Economic Crisis: Assessing the Short-Term Impact in OECD Countries; OECD Health Working Papers, No. 76; OECD Publishing: Paris, France, 2014.

63. Palumbo, R. Contextualizing co-production of health care: A systematic literature review. Int. J. Pub. Sect. Manag. 2016, 29, 72-90. [CrossRef]

64. Mattila, M.; Rapeli, L. Just sick of it? Health and political trust in Western Europe. Eur. J. Pol. Res. 2018, 57, 116-134. [CrossRef]

65. Buffoli, M.; Capolongo, S.; Bottero, M.; Cavagliato, E.; Speranza, S.; Volpatti, L. Sustainable healthcare: How to assess and improve healthcare structures' sustainability. Ann. Ig 2013, 25, 411-418. [PubMed]

66. Garcés, J.; Ródenas, F.; Sanjosé, V. Towards a new welfare state: The social sustainability principle and health care strategies. Health Policy 2013, 65, 201-215. [CrossRef]

67. McKenzie, S. Social Sustainability: Towards Some Definitions; University of South Australia, Hawke Research Institute: Magill, Australia, 2004.

68. Capolongo, S.; Bottero, M.C.; Lettieri, E.; Buffoli, M.; Bellagarda, A.; Birocchi, M.; Cavagliato, E.; Dervishaj, A.; di Noia, M.; Gherardi, G.; et al. Healthcare Sustainability Challenge. In Improving Sustainability during Hospital Design and Operation. Green Energy and Technology; Capolongo, S., Bottero, M., Buffoli, M., Lettieri, E., Eds.; Springer: Cham, Switzerland, 2015; pp. 1-9.

69. Beckfield, J.; Olafsdottir, S.; Sosnaud, B. Healthcare Systems in Comparative Perspective: Classification, Convergence, Institutions, Inequalities, and Five Missed Turns. Ann. Rev. Soc. 2013, 39, 127-146. [CrossRef] [PubMed]

70. Volandes, A.E.; Paasche-Orlow, M.K. Health Literacy, Health Inequality and a Just Healthcare System. Am. J. Bioeth. 2007, 7, 5-10. [CrossRef] [PubMed]

71. Palumbo, R. Examining the impacts of health literacy on healthcare costs. An evidence synthesis. Health Serv. Manag. Res. 2017, 30, 197-212. [CrossRef] [PubMed]

72. Henwood, M.; Hudson, B. Lost to the System? The Impact of Fair Access to Care; UK Government Department of Health, Commission for Social Care Inspection: London, UK, 2008.

73. Seeleman, C.; Essink-Bot, M.L.; Stronks, K.; Ingleby, D. How should health service organizations respond to diversity? A content analysis of six approaches. BMC Health Serv. Res. 2015, 15, 510. [CrossRef] [PubMed]

74. Adinolfi, P.; Adinolfi, R. Rethinking Gender and Health: Some Insights from the Italian Experience. Int. J. Men Health 2013, 12, 42-62. [CrossRef]

75. Cruz, T.M. Assessing access to care for transgender and gender nonconforming people: A consideration of diversity in combating discrimination. Soc. Sci. Med. 2014, 110, 65-73. [CrossRef] [PubMed]

76. Adinolfi, P. "Bamboccioni" and "Mammoni"? A Familistic Interpretation of Italian Men's Unhealthy Behaviours. Int. J. Men Health 2013, 12, 63-79. [CrossRef]

77. Carrasco, C. Beyond Equality: Towards a System of Non-Androcentric Indicators. In Gender and Well-Being in Europe: Historical and Contemporary Perspectives; Harris, B., Gálvez, L., Machado, H., Eds.; Routledge: London, UK, 2016; pp. 185-201. 
78. Bergeson, S.C.; Dean, J.D. A systems approach to patient-centered care. JAMA 2006, 296, $2848-2851$. [CrossRef] [PubMed]

79. Palumbo, R.; Annarumma, C.; Musella, M.; Adinolfi, P. A recipe for excellence in health care: Investigating the relationship between health literacy, self-efficacy, awareness, and health services' use. Sinergie Ital. J. Manag. 2018, 36. Available online: https:/ /www.sijm.it/journal (accessed on 25 November 2018).

80. Palumbo, R.; Annarumma, C.; Adinolfi, P.; Musella, M.; Piscopo, G. The Italian Health Literacy Project: Insights from the assessment of health literacy skills in Italy. Health Policy 2016, 120, 1087-1094. [CrossRef] [PubMed]

81. Kickbush, I. Health literacy: An essential skill for the twenty-first century. Health Educ. 2008, 108, 101-104. [CrossRef]

82. Willis, C.D.; Saul, J.E.; Bitz, J.; Pompu, K.; Best, A.; Jackson, B. Improving organizational capacity to address health literacy in public health: A rapid realist review. Public Health 2014, 128, 515-524. [CrossRef] [PubMed]

83. Weaver, N.L.; Wray, R.J.; Zellin, S.; Gautam, K.J.K. Advancing Organizational Health Literacy in Health Care Organizations Serving High-Needs Populations: A Case Study. J. Health Commun. 2012, 17, 55-66. [CrossRef] [PubMed]

84. Utley, R. Care and Caring Frameworks. In Frameworks for Advanced Nursing Practice and Research: Philosophies, Theories, Models, and Taxonomies; Utley, R., Henry, K., Smith, L., Eds.; Springer: New York, NY, USA, 2018; pp. 57-70.

85. Palumbo, R. The Bright Side and the Dark Side of Patient Empowerment: Co-Creation and Co-Destruction of Value in the Healthcare Environment; Springer: Cham, Switzerland, 2017.

86. Carnero, M.C. Assessment of Environmental Sustainability in Health Care Organizations. Sustainability 2015, 7,8270-8291. [CrossRef]

87. Jameton, A.; Pierce, J. Environment and health: 8. Sustainable health care and emerging ethical responsibilities. Can. Med. Assoc. J. 2001, 164, 365-369.

88. Mohrman, S.A.; Shani, A.B. Organizing for Sustainable Healthcare; Emerald: Bingley, UK, 2012.

89. Kear, R.; Whiteley, N.; Abercrombie, N. The Authority of the Consumer; Routledge: New York, NY, USA, 2005.

90. Aujoulat, I.; d'Hoore, W.; Deccache, A. Patient empowerment in theory and practice: Polysemy or cacophony? Patient Educ. Couns. 2007, 66, 13-20. [CrossRef] [PubMed]

91. Palumbo, R.; Annarumma, C.; Adinolfi, P.; Musella, M. The missing link to patient engagement in Italy. J. Health Organ Manag. 2016, 30, 1183-1203. [CrossRef] [PubMed]

92. Bodenheimer, T.; Lorig, K.; Holman, H.; Grumbach, K. Patient Self-management of Chronic Disease in Primary Care. JAMA 2002, 288, 2469-2475. [CrossRef] [PubMed]

93. Pulvirenti, M.; McMillan, J.; Lawn, S. Empowerment, patient centred care and self-management. Health Expect. 2014, 17, 303-310. [CrossRef] [PubMed]

94. De Belvis, A.G.; Ferrè, F.; Specchia, M.L.; Valerio, L.; Fattore, G.; Ricciardi, W. The financial crisis in Italy: Implications for the healthcare sector. Health Policy 2012, 106, 10-16. [CrossRef] [PubMed]

95. Hunter, D.J. The impact of the spending review on health and social care. Brit. Med. J. 2010, 341. [CrossRef] [PubMed]

96. Kyriopoulos, I.I.; Zavras, D.; Skroumpelos, A.; Mylona, K.; Athanasakis, K.; Kyriopoulos, J. Barriers in access to healthcare services for chronic patients in times of austerity: An empirical approach in Greece. Int. J. Equity Health 2014, 13. [CrossRef] [PubMed]

97. Legido-Quigley, H.; Otero, L.; la Parra, D.; Alvarez-Dardet, C.; Martin-Moreno, J.M.; McKee, M. Will austerity cuts dismantle the Spanish healthcare system? Br. Med. J. 2013, 346. [CrossRef] [PubMed]

98. Lopez-Valcarcel, B.G.; Barber, P. Economic Crisis, Austerity Policies, Health and Fairness: Lessons Learned in Spain. Appl. Health Econ. Health Policy 2017, 15, 13-21. [CrossRef] [PubMed]

99. Majeed, A. Primary care in Europe: Entering the age of austerity. J. Ambul. Care Manag. 2012, 35, 162-166. [CrossRef] [PubMed]

100. Bailey, D. The Environmental Paradox of the Welfare State: The Dynamics of Sustainability. New Pol. Econ. 2015, 20, 793-811. [CrossRef]

101. Garrison, L.P.J. Universal Health Coverage-Big Thinking versus Big Data. Value Health 2013, 16, 1-3. [CrossRef] [PubMed] 
102. Grimmeisen, S.; Frisina, L. The Role of the State in the British Healthcare System-Between Marketization and Statism. In The State and Healthcare. Transformations of the State; Rothgang, H., Cacace, M., Frisina, L., Grimmeisen, S., Schmid, A., Wendt, C., Eds.; Palgrave Macmillan: London, UK, 2010; pp. 75-118.

103. Casamatta, G.; Cremer, H.; Pestieau, P. Political sustainability and the design of social insurance. J. Pub. Econ. 2000, 75, 341-364. [CrossRef]

104. March, M.; Schroyen, F. Can a Mixed Health Care System Be Desirable on Equity Grounds? Scand. J. Econ. 2005, 107, 1-23. [CrossRef]

105. Glimmerveen, L.; Ybema, S.; Nies, H. Empowering citizens or mining resources? The contested domain of citizen engagement in professional care services. Soc. Sci. Med. 2018, 203, 1-8. [CrossRef] [PubMed]

106. Olsen, I.T. Sustainability of Health Care: A Framework for Analysis. Health Policy Plan. 1998, 13, $287-295$. [CrossRef] [PubMed]

107. Borgonovi, E. Healthcare system: Issues of sustainability and economic growth. Int. Rev. Soc. Sci. 2017, 3, 231-248.

108. Mintzberg, H. Rebalancing Society. Radical Renewal Beyond Left, Right, and Center; Berrett-Koehler: Oakland, CA, USA, 2014.

109. Compagni, A.; Fosti, G.; Longo, F.; Tozzi, V.; Amatucci, F.; Armeni, P.; Callea, G.; Ciani, O.; Cusumano, N.; Jommi, C.; et al. SSN fast forward. Proposals to make the most effective, equitable and sustainable National Health Service. Mecosan 2016, 24, 101-124.

110. Maynard, A. The Public-Private Mix for Health: Plus Ça Change, Plus C'est la Même Chose? Radcliffe Publishing: Oxford, UK, 2005.

111. Maarse, H. The Privatization of Health Care in Europe: An Eight-Country Analysis. J. Health Polit. Policy Law 2006, 31, 981-1014. [CrossRef] [PubMed]

112. Larson, P. Public and private values at odds: Can private sector values be transplanted into public sector institutions? Pub. Adm. Dev. 1997, 17, 131-139. [CrossRef]

113. Basu, S.; Andrews, J.; Kishore, S.; Panjabi, R.; Stuckler, D. Comparative Performance of Private and Public Healthcare Systems in Low- and Middle-Income Countries: A Systematic Review. PLoS Med. 2012, 9, e1001244. [CrossRef] [PubMed]

114. Roehrich, J.K.; Lewis, M.A.; George, G. Are public-private partnerships a healthy option? A systematic literature review. Soc. Sci. Med. 2014, 113, 110-119. [CrossRef] [PubMed]

115. Akinci, F.; Mollahaliloğlu, S.; Gürsöz, H.; Öğücü, F. Assessment of the Turkish health care system reforms: A stakeholder analysis. Health Policy 2012, 107, 21-30. [CrossRef] [PubMed]

116. Ramirez, B.J.; West, D.M.; Costell, M. Development of a culture of sustainability in health care organizations. J. Health Organ. Manag. 2013, 27, 665-672. [CrossRef] [PubMed]

117. Birch, S.; Murphy, G.T.; MacKenzie, A.; Cumming, J. In place of fear: Aligning health care planning with system objectives to achieve financial sustainability. J. Health Serv. Res. Policy 2015, 20, 109-114. [CrossRef] [PubMed]

118. Adinolfi, P.; Borgonovi, E. The Myths of Health Care. Towards New Models of Leadership and Management in the Healthcare Sector; Springer: Berlin, Germany, 2018.

119. Towle, A.; Godolphin, W. Patients as educators: Interprofessional learning for patient-centred care. Med. Teach. 2013, 35, 219-225. [CrossRef] [PubMed]

120. Frow, P.; McColl-Kennedy, J.R.; Payne, A. Co-creation practices: Their role in shaping a health care ecosystem. Ind. Mark. Manag. 2016, 56, 24-39. [CrossRef]

(c) 2018 by the authors. Licensee MDPI, Basel, Switzerland. This article is an open access article distributed under the terms and conditions of the Creative Commons Attribution (CC BY) license (http://creativecommons.org/licenses/by/4.0/). 